\title{
Pengaruh Motivasi Kerja dan Disiplin Kerja Terhadap Kinerja Karyawan Instalasi Gizi RSUP Dr. Mohammad Hoesin Palembang
}

\author{
Anggreany Hustia \\ Universitas Muhammadiyah Palembang \\ Email: reanyhustia1012@gmail.com
}

\begin{abstract}
The research was to determine the effect of motivation and discipline on employee performances. The sample was 56 employees of the Nutrition Installation at Dr. Mohammad Hoesin Palembang. Type of research was associative. The primary and secondary data used to know the information about the company and respondence with shared the questionnaire about work motivation and discipline. The method of data analysis used qualitative method which was then quantified. The techinique of data analysis used multiple linear regression analysis. The results showed that it is true that work discipline and motivation are very important aspects in influencing the performance of employees in Nutrition Installation at RSUP Dr. Mohammad Hoesin Palembang based on the F test and test with conviction level of $90 \%$.
\end{abstract}

Keywords: work motivation, work discipline and employee performance

\section{Pendahuluan}

RSUP Dr. Mohammad Hoesin Palembang adalah rumah sakit bertipe A yang berada di Kota Palembang. Memiliki akreditasi rumah sakit dengan tipe A ini bukanlah hal yang mudah, maka RSUP Dr. Mohammad Hoesin Palembang selalu berusaha terus melakukan peningkatan kualitas dalam pelayanannya. Peningkatan pelayanan ini sangat bergantung pada tenaga sumber daya manusia atau karyawan yang berkualitas. Dengan kata lain kualitas kinerja karyawan merupakan salah satu faktor penentu keberhasilan perusahaan atau organisasi dalam mencapai tujuannya.

RSUP Dr. Mohammad Hoesin Palembang memiliki karyawan yang tersebar dalam berapa bagian instalasi kesehatan, mulai dari karyawan medis, perawat dan penunjang medis, karyawan non medis dan non paramedis. Dengan banyaknya karyawan RSUP Dr.Mohammad Hoesin Palembang melakukan penilaian kinerja rutin setiap bulan kepada semua karyawan. Khususnya pada Instalasi Gizi penilaian ini bertujuan untuk mengetahui kualitas dan ketepatan waktu karyawan dalam pelayanan pasien, mengetahui apakah semua karyawan telah menjalanan tugas sesuai Standar Prosedur Operasional (SPO), dan menilai tanggung jawab karyawan atas pekerjaannya. Hasil penilaian kinerja digunakan sebagai bahan pertimbangan dalam pembinaan karyawan, antara lain pengangkatan, kenaikan pangkat, pengangkatan dalam jabatan, pendidikan dan pelatihan, serta pemberian penghargaan. Unsur-unsur yang dinilai dalam melaksanakan penilaian pelaksanaan pekerjaan adalah kesetiaan, prestasi kerja, tanggung jawab, ketaatan, kejujuran, kerjasama dan kepemimpian. Adapun standar-standar atau nilai-nilai pelaksanaan pekerjaan tersebut adalah rata-rata dari nilai sub-sub unsur penilaian yang di terapkan di instalasi gizi RSUP Dr.Mohamad Hoesin Palembang. Hasil penilaian pelaksanaan pekerjaan dituangkan dalam daftar penilaian pelaksanaan pekerjaan yaitu: amat baik (91-100), baik (76-90), cukup (61-75), sedang (51-60). Karyawan yang memiliki hasil kerja yang berkualitas dan memperoleh nilai dalam predikat amat baik yaitu 91- 
100 adalah harapan top manajemen.

Hasil penilaian kinerja yang dilakukan secara rutin ini terutama pada karyawan Instalasi Gizi belum sepenuhnya tercapai. Dalam proses pelayanan maupun ketepatan waktu dalam pekerjaan masih dianggap kurang berkualitas disebabkan karena kerja sama antar karyawan yang belum terjalin dengan baik serta karyawan masih banyak tidak mengikuti standar. Permasalahan inilah yang harus diperbaiki oleh kepala instalasi dengan menggunakan strategi yang tepat agar kinerja karyawan menjadi baik dan pelayanan terhadap pasien menjadi lebih baik dan berkualitas.

Strategi dalam menghasilkan kinerja karyawan yang baik ini yang perlu diperhatikan oleh top manajemen salah satunya motivasi kerja. Menurut (Handoko 2003) motivasi adalah keadaan pribadi seseorang yang mendorong keinginan individu untuk melakukan kegiatan tertentu guna mencapai tujuan. Dari definisi tersebut motivasi dapat dikatakan menjadi faktor yang mendorong adanya perilaku seseorang untuk melakukan suatu kegiatan tertentu. Karyawan RSUP Dr. Mohammad Hoesin Palembang sangat membutuhkan adanya motivasi yang tinggi untuk kinerja yang baik terlebih saat ini sedang terjadinya pandemik Covid 19. Mudahnya virus covid 19 ini menyebar mengakibatkan pasien yang terinfeksi virus sangat banyak dirawat di Rumah Sakit. Mereka yang terinfeksi adalah orang-orang yang dalam 14 hari sebelum muncul gejala melakukan perjalanan dari negara terjangkit, atau yang kontak erat, seperti anggota keluarga, rekan kerja atau tenaga medis yang merawat pasien sebelum mereka tahu pasien tersebut terinfeksi COVID-19. Oleh sebab itu, kondisi kerja pada masa pandemik ini khususnya bagi karyawan Instalasi Gizi sebagai petugas Pramusaji dan Ahli Gizi timbul rasa ketakutan dan ketidak nyamanan dalam bekerja.

Fasilitas kerja yang memadai seperti Alat Pelindung Diri (APD) dan Rapid Test dan hasil PCR (polymerase chain reaction) atau biasa disebut dengan tes swab rutin bagi karyawan sangat diperlukan karena petugas kesehatan berisiko lebih tinggi dan harus konsisten melindungi diri dengan prosedur pencegahan dan pengendalian infeksi yang tepat. Selain itu, resiko akan pekerjaan itu sendiri walaupun sudah Alat Pelindung Diri (APD) lengkap namun karena ditahap awal pasien datang ke rumah sakit tidak langsung dapat ditempatkan diruangan khusus dikarenakan lamanya informasi dari hasil pelaksanaan Rapid Test dan hasil PCR (polymerase chain reaction) atau biasa disebut dengan tes swab bagi pasien. Beberapa hal tersebut baik kondisi kerja, fasilitas kerja dan perkerjaan itu sendiri membuat karyawan di instalasi gizi terutama Pramusaji dan Ahli Gizi yang harus berkomunikasi dan berkolaborasi bersama perawat dan dokter sangat membuat kekhawatiran bagi karyawan yang mengganggu ketentraman dan dorongan melakukan pekerjaan. Hal ini sesuai dengan yang dikatakan oleh (Afandi 2016) bahwa dimensi dan indikator motivasi adalah dimensi ketentraman dan dimensi dorongan.

Faktor lain yang dapat mempengaruhi kinerja karyawan adalah disiplin kerja karyawan. Menurut (Hasibuan, 2014) kedisiplinan merupakan kesadaran dan kesediaan seseorang menaati semua peraturan-peraturan perusahaan dan norma-norma sosial yang berlaku. Disiplin kerja karyawan merupakan faktor yang harus diperhatikan oleh bagian Sumber Daya Manusia RSUP Dr.Mohammad Hoesin Palembang, yang ditujukan untuk memenuhi standar kinerja yang telah ditetapkan oleh Instalasi tersebut. Karyawan dituntut untuk memiliki disiplin yang tinggi dalam melakukan suatu pekerjaan namun disiplin berkaitan dengan peraturan rumah sakit tidak sepenuhnya diikuti oleh semua karyawan. Terlihat dari Masuk kerja tepat waktu, meskipun sudah ada aturan yang jelas mengenai jam bekerja tetap saja karyawan sering datang terlambat. Masih ada karyawan mangkir atau tidak kerja dengan menambah libur diluar jadwal 
yang telah dibuat. Karyawan juga belum Mematuhi semua peraturan rumah sakit misalkan penggunaan seragam yang tidak sesuai jadwalnya, kepatuhan dalam menggunaan Alat Pelindung Diri (APD) dan mencuci tangan sebelum dan setelah melakukan pekerjaan terlebih di masa pandemik ini. Pernyataan tersebut didukung oleh hasil pra penelitian yang peneliti lakukan dengan melakukan wawancara kepada beberapa karyawan yang bekerja di Instalasi Gizi RSUP Dr. Mohammad Hoesin menyatakan bahwa kedisiplinan di instalasi tersebut dinilai masih belum maksimal terlebih di tahun 2020 ini. Menurut (Afandi 2016) bahwa dimensi dan indikator disiplin yaitu Dimesi ketaatan waktu dan dimensi tanggung jawab kerja.

Menurut (Marpaung 2014) mengatakan bahwa motivasi dan disiplin kerja merupakan salah satu faktor penting yang mempengaruhi kinerja karyawan. Artinya kedua faktor ini motivasi dan disiplin merupakan hal utama yang perlu diperhatikan oleh manajemen RSUP Dr. Mohammad Hoesin untuk menjaga kualitas dan ketepatan waktu dalam memberikan pelayanan yang ada dirumah sakit. Dimana hal inilah yang menjadi penentu baik buruknya kinerja organisasi.

Berdasarkan penjelasan di atas, maka penelitian ini berfokus pada masalah: 1) Apakah motivasi kerja berpengaruh terhadap kinerja karyawan?; 2) Apakah disiplin kerja berpengaruh terhadap kinerja karyawan?; 3) Apakah motivasi kerja dan disiplin kerja berpengaruh terhadap kinerja karyawan?;

Beberapa penelitian yang relevan dengan penelitian ini antara lain: Penelitian (Farhah, Ahiri, and Ilham 2020) yang berjudul pengaruh motivasi kerja dan disiplin kerja terhadap kinerja karyawan dengan objek penelitian PT. Kalla Kakao Industri mengatakan bahwa secara total motivasi kerja dan disiplin kerja berpengaruh signifikan terhadap kinerja karyawan sebesar 62,60 persen. Penelitian (Marpaung 2014) yang berjudul pengaruh motivasi dan disiplin kerja terhadap kinerja karyawan (Studi Pada Karyawan Rumah Sakit Reksa Waluya Mojokerto) menyatakan bahwa masing-masing motivasi dan disiplin kerja yang digunakan dalam penelitian memiliki pengaruh yang signifikan dan menunjukkan hasil positif, yang artinya bahwa dengan adanya motivasi tinggi dan dengan kesadaran lebih dalam berdisiplin maka akan mempengaruhi kinerja karyawan. Penelitian. Penelitian (Setiawan, 2013) yang berjudul pengaruh disiplin kerja dan motivasi terhadap kinerja karyawan pada Rumah Sakit Umum Daerah Kanjuruhan Malang, menyimpulkan bahwa motivasi dan disiplin kerja berpengaruh positif secara parsial maupun simultan terhadap kinerja karyawan. Penelitian (Suwanto 2019) yang berjudul pengaruh disiplin kerja dan motivasi kerja terhadap kinerja karyawan pada Rumah Sakit Umum Tangerang Selatan menunjukan bahwa disiplin kerja dan motivasi kerja secara simultan (bersama-sama) mempengaruhi kinerja karyawan sebesar 64,1\%. Keempat hasil penelitian tersebut menyimpulkan bahwa motivasi kerja dan disiplin kerja berpengaruh berpengaruh terhadap kinerja.

\section{Tinjauan Literatur}

\subsection{Kinerja}

Menurut (Anwar Prabu, 2017) kinerja adalah pelaksanaan tanggung jawab karyawan dengan pencapaian hasil kerja sesuai dengan kualitas dan kuantitas yang ada didalam perusahaan.

Menurut (Kasmir, 2016), faktor-faktor yang mempengaruhi kinerja karyawan yaitu: kemampuan dan keahlian, pengetahuan, rancangan kerja, kepribadian, motivasi kerja, kepemimpinan, gaya kepemimpinan, budaya organisasi, kepuasan kerja, lingkungan kerja, loyalitas, komitmen, dan disiplin kerja. 
Menurut Dharma dalam (Marpaung 2014) ada tiga standar pengukuran kinerja yaitu: a) Kuantitas, yaitu berhubungan dengan jumlah yang dihasilkan dan jumlah yang harus diselesaikan atau dicapai oleh karyawan, b) Kualitas, yaitu berhubungan dengan baik tidaknya mutu yang dihasilkan oleh karyawan, dan c) Ketepatan waktu, berhubungan dengan pengukuran waktu penyelesaian pekerjaan yang dilakukan oleh karyawan.

Kinerja merupakan hasil kerja yang di capai secara baik dan buruk sifat, sikap, cara kerja dalam melaksanakan tugas dan tanggung jawab yang diberikan pada karyawan gizi RSUP Dr.Mohammad Hoesin Palembang.

\subsection{Motivasi}

Menurut (Edy, 2009), motivasi adalah suatu faktor yang mendorong seseorang untuk melakukan suatu aktivitas tertentu, oleh karena itu motivasi sering kali diartikan pula sebagai faktor pendorong perilaku seseorang. Dengan adanya motivasi ini maka para karyawan akan bersemangat dalam melaksanakan tugas dan pekerjaannya.

Menurut (Afandi, 2016) dimensi dan indikator kerja dilihat dari dua dimensi yaitu pertama, dimensi ketentraman yang merupakan rasa senang, nyaman dan bersemangat karena keputusan terpenuhi. Dengan indikatornya adalah balas jasa, kondisi kerja dan fasilitas kerja. Kedua, dimensi dorongan untuk dapat bekerja sebaik mungkin. Dengan indikatornya adalah prestasi kerja, pengakuan dari atasan dan pekerjaan itu sendiri.

\subsection{Disiplin}

Menurut Singodimedjo dalam (Edy, 2009) mengatakan bahwa disiplin kerja adalah sikap keadilan dan kerelaan seseorang untuk memenuhi dan menaati norma-norma peraturan yang berlaku disekitarnya. Kerelaan ini adalah sikap seorang yang secara ikhlas menaati semua peraturan dan sadar akan tugas dengan baik bukan atas paksaan dan tahu akan tanggung jawabnya.

Menurut Rivai (Rivai, 2013) indikator disiplin kerja ialah : kehadiran, ketaatan pada peraturan kerja, ketaatan pada standar kerja, tingkat kewaspadaan tinggi, dan bekerja etis.

Menurut (Afandi 2016) dimensi dan indikator disiplin kerja dilihat dari dua dimensi yaitu pertama dimensi ketaatan waktu dengan indikator masuk kerja tepat waktu, pengunaan waktu secara efektif, dan tidak pernah mangkir/ tidak kerja. Kedua, dimensoi tanggung jawab kerja, dengan indikator mematuhi semua peraturan organisasi atau perusahaan, target pekerjaan dan membuat laporan kerja harian.

\section{Metode Penelitian}

Jenis penelitian yang digunakan dalam penelitian ini adalah berjenis penelitian asosiatif. Menurut (Sugiyono, 2017) penelitian asosiatif yaitu untuk mengetahui pengaruh motivasi kerja dan disiplin kerja terhadap kinerja karyawan. Karyawan Instalasi Gizi di RSUP Dr.Mohammad Hoesin Palembang yang berjumlah 129 orang dijadikan sebagai populasi penelitian namun yang dijadikan sebagai sampel hanya sebanyak 56 orang responden, dengan menggunakan teknik Cluster Random Sampling. Data yang digunakan dalam penelitian ini adalah data primer dan sekunder. Hasil dari pembagian kuesioner kepada para responden dijadikan sebagai data primer, sedangkan semua informasi yang diperoleh secara langsung dari perusahaan sebagai objek penelitian ataupun dari berbagai literasi dijadikan sebagai data sekunder.

Metode analisis yang digunakan dalam penelitian ini adalah Metode Analisis Regresi Linier Berganda, dan dianalisis dengan menggunakan program komputer (software) SPSS versi 25. 
Analisis ini digunakan untuk menilai pengaruh motivasi kerja dan disiplin kerja terhadap kinerja karyawan Instalasi Gizi RSUP Dr. Mohammad Hoesin Palembang. Sebelum melakukan analisis regresi terlebih dahulu dilakukan uji instrument atas kuesioner yang akan disebar sebagai sumber data. Adapun uji instrument yang dilakukan adalah uji validitas dan uji reliabilitas.

Model analisis statistik digambarkan dalam bentuk diagram berikut ini:

Gambar 1. Model Analisis Penelitian

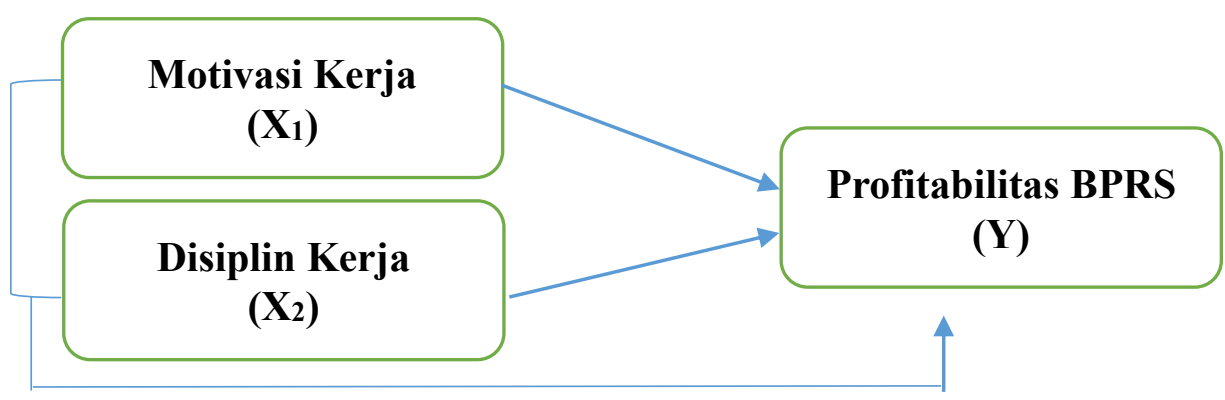

Sumber: Penulis, 2020

Persamaan Regresi Linear Berganda:

$\mathbf{Y}=\mathbf{a}+\mathbf{b}_{1} \mathbf{X}_{1}+\mathbf{b}_{2} \mathbf{X}_{2}+\mathbf{e}$

Dimana :

$$
\begin{aligned}
& \mathrm{Y}=\text { Kinerja Karyawan } \\
& \mathrm{a}=\text { Konstanta } \\
& \mathrm{b}_{1}=\text { Koefisen Regresi Variabel Motivasi Kerja } \\
& \mathrm{X}_{1}=\text { Motivasi Kerja } \\
& \mathrm{b}_{2}=\text { Koefisen Regresi Variabel Disiplin Kerja } \\
& \mathrm{X}_{2}=\text { Disiplin Kerja } \\
& \mathrm{e}=\text { error }
\end{aligned}
$$

Dalam melakukan pengujian hipotesis atas masalah penelitian maka penelitan ini dilakukan uji $\mathrm{F}$ dan uji t. Uji $\mathrm{F}$ untuk mengetahui pengaruh motivasi kerja dan disiplin kerja secara Bersamasama terhadap kinerja karyawan. sedangkan uji t dilakukan untuk mengetahui pengaruh motivasi kerja atau disiplin kerja secara parsial terhadap kinerja karyawan.

\section{Hasil dan Pembahasan}

\subsection{Hasil Penelitian}

\subsubsection{Uji Instrumen}

Uji instrumen ini digunakan untuk menilai keabsahan dari butir-butir pernyataan disetiap indikator sehingga butir pernyataan tersebut dapat dikatakan layak digunakan dan dapat dinilai dalam kelanjutan proses análisis penelitian. Dalam penelitian ini uji instrumen disebar kepada 30 orang karyawan yang kemudian dilakukan pengujian uji validitas dan uji reliabilitas terhadap 18 butir pernyataan kuesioner. Berdasarkan hasil uji validitas secara keseluruhan ítem pada setiap indikator yang digunakan pada setiap butir pernyataan dalam kuesioner dinyatakan valid, hal ini dikarenakan nilai $r_{h i t u n g}$ pada semua butir pernyataan dinyatakan lebih besar dari 
$\mathrm{r}_{\text {tabel }}$ yang nilainya sebesar 0,361 . Kemudian berdasarkan hasil uji reliabilitas diketahui bahwa keseluruhan indikator yang digunakan pada setiap butir pernyataan dalam penelitian ini dikatakan reliabel, karena keseluruhan indikator yang digunakan memiliki nilai lebih dari 0,6. Disimpulkan bahwa semua butir pernyataan dalam kuesioner digunakan dalam analisis data penelitian.

\subsubsection{Hasil Regresi Linier Berganda}

Tabel 1. Regresi Linier Berganda

\begin{tabular}{ccccc}
\hline & & \multicolumn{2}{c}{ Unstandardized Coefficients } & Standardized Coefficients \\
\cline { 3 - 5 } & Model & B & Std. Error & Beta \\
\hline 1 & (Constant) &, 386 &, 232 & \\
& Motivasi Kerja &, 526 &, 082 &, 556 \\
& Disiplin Kerja &, 347 &, 098 &, 337 \\
\hline
\end{tabular}

Sumber: Berdasarkan hasil perhitungan SPSS, 2020

Dari hasil tersebut dapat dijabarkan anallisis regresi linier berganda sebagai berikut:

$Y=0,386+0,526 X_{1}+0,347 X_{2}$

Dari analisis regresi linier berganda tersebut dapat dinyatakan tiga kesimpulan. Pertama, nilai konstanta sebesar 0,386 berbentuk positif, dapat diartikan jika variabel motivasi kerja dan disiplin kerja tidak ada atau bernilai 0 (nol), maka nilai kinerja karyawan ada sebesar 0,386. Kedua, nilai koefisien motivasi kerja sebesar 0,526 berbentuk positif dapat menjelaskan bahwa adanya pengaruh antara motivasi kerja dengan kinerja karyawan, dengan demikian setiap adanya peningkatan motivasi kerja sebesar nilai koefisien tersebut maka kinerja karyawan akan berdampak naik dan sebaliknya jika menurun maka kinerja akan turun. Dan ketiga, nilai koefisien disiplin kerja sebesar 0,347 berbentuk positif dapat menjelaskan bahwa adanya pengaruh antara disiplin kerja dengan kinerja karyawan, dengan demikian setiap adanya peningkatan disiplin kerja sebesar nilai koefisien tersebut maka kinerja karyawan akan berdampak naik dan sebaliknya jika menurun maka kinerja akan turun.

\subsubsection{Uji Hipotesis Secara Bersama-Sama (Uji F/Simultan)}

Tabel 2. Hasil Hipotesis Secara Bersama-Sama/ Simultan (Uji f)

\section{ANOVA $^{b}$}

\begin{tabular}{ccccccc}
\hline & Model & Sum of Squares & Df & Mean Square & F & Sig. \\
\hline 1 & Regression & 28,779 & 2 & 14,389 & 62,291 &, $000^{\mathrm{a}}$ \\
& Residual & 12,243 & 54 &, 231 & & \\
& Total & 41,022 & 56 & & & \\
\hline
\end{tabular}

Sumber: Berdasarkan hasil perhitungan SPSS, 2020

Berdasarkan tabel hasil uji hipotesis secara bersama-sama/ simultan, dapat diartikan bahwa motivasi kerja dan disiplin yang merupakan variabel bebas berpengaruh secara bersama-sama terhadap kinerja karyawan yang merupakan variabel terikat. Hal ini dapat dilihat bahwa nilai

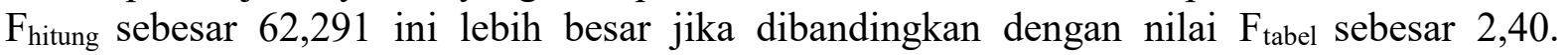
Kemudian diperkuat dengan tingkat sig. F sebesar 0,000 yang menjelaskan bahwa nilai ini lebih kecil dari ketetapan tingkat kesalahan sebesar 10\% atau 0,1, maka ini diartikan bahwa Ho ditolak, artinya ada pengaruh signifikan motivasi kerja dan disiplin kerja terhadap kinerja 
karyawan instalasi gizi RSUP Dr. Mohammad Hoesin Palembang.

4.1.4. Uji Hipotesis Secara Individual / Uji t (Parsial)

Tabel 3. Hasil Hipotesis Secara Individual/Parsial (Uji t)

Coefficients $^{\mathbf{a}}$

\begin{tabular}{cccccc}
\hline \multirow{2}{*}{ Model } & \multicolumn{2}{c}{ Unstandardized Coefficients } & \multicolumn{2}{c}{$\begin{array}{c}\text { Standardized } \\
\text { Coefficients }\end{array}$} \\
\cline { 2 - 4 } & B & Std. Error & Beta & T & Sig. \\
\cline { 2 - 4 } (Constant) &, 386 &, 232 & & 1,533 &, 131 \\
Motivasi Kerja &, 526 &, 082 &, 556 & 6,141 &, 000 \\
Disiplin Kerja &, 347 &, 098 &, 337 & 3,535 &, 001 \\
\hline
\end{tabular}

Sumber: Berdasarkan hasil perhitungan SPSS, 2020

Berdasarkan tabel hasil uji hipotesis secara individual/ parsial, dapat diartikan bahwa terdapat pengaruh antara motivasi kerja atau disiplin kerja secara parsial terhadap kinerja karyawan. Hal ini dapat dilihat dan dijelaskan dari hasil perbandingan nilai thitunglebih besar dari nilai tabel yang nilainya sebesar 1,297 .

Pertama, dari tabel di dapat bahwa $t_{\text {hitung }}$ untuk motivasi kerja nilainya sebesar 6,141 nilai ini lebih besar dari nilai $t_{\text {tabel }}$ sebesar 1,297. Diperkuat dengan tingkat sig. $t$ sebesar 0,000 yang menjelaskan bahwa nilai ini lebih kecil dari ketetapan tingkat kesalahan sebesar $10 \%$ atau 0,1 , maka Ho ditolak, artinya ada pengaruh signifikan motivasi kerja terhadap kinerja karyawan instalasi gizi RSUP Dr. Mohammad Hoesin Palembang.

Kedua, dari tabel di dapat bahwa $t_{\text {hitung }}$ untuk disiplin kerja nilainya sebesar 3,535 dimana nilai ini lebih besar dari nilai tabel sebesar 1,297. Diperkuat dengan tingkat sig. $t$ sebesar 0,001 yang menjelaskan bahwa nilai ini lebih kecil dari ketetapan tingkat kesalahan sebesar $10 \%$ atau 0,1 , maka Ho ditolak, artinya ada pengaruh signifikan disiplin kerja terhadap kinerja karyawan instalasi gizi RSUP Dr. Mohammad Hoesin Palembang.

\subsubsection{Uji Koefisien Determinasi $\left(\mathrm{R}^{2}\right)$}

Hasil analisis ini dapat dilihat pada tabel berikut ini :

Tabel 6. Koefisien Determinasi

Model Summary

\begin{tabular}{ccccc}
\hline Model & R & R Square & Adjusted R Square & Std. Error of the Estimate \\
\hline 1 &, $838^{\mathrm{a}}$ &, 702 &, 690 &, 481 \\
\hline
\end{tabular}

Sumber: Berdasarkan hasil perhitungan SPSS, 2020

Berdasarkan tabel di atas, diperoleh nilai Adjusted R Square (koefisien determinasi) sebesar 0,690, artinya variabel motivasi kerja dan disiplin kerja memilliki berkonstribusi terhadap naik turunnya kinerja karyawan sebesar 69\%. Sedangkan sisanya sebesar 31\% dijelaskan oleh variabel-variabel lain yang tidak termasuk dalam penelitian ini. 


\subsection{Pembahasan}

Hasil analisis regresi linier berganda, diketahui adanya pengaruh yang positif dari motivasi kerja dan disiplin kerja terhadap kinerja karyawan instalasi gizi RSUP Dr. Mohammad Hoesin Palembang. Hasil uji hipotesis secara simultan menunjukkan bahwa ada pengaruh yang signifikan motivasi kerja dan disiplin kerja terhadap kinerja karyawan instalasi gizi RSUP Dr. Mohammad Hoesin Palembang. Hasil uji hipotesis secara parsial, menunjukan ada pengaruh yang signifikan motivasi kerja terhadap kinerja karyawan instalasi gizi RSUP Dr. Mohammad Hoesin Palembang. Dan ada pengaruh yang signifikan disiplin kerja terhadap kinerja karyawan instalasi gizi RSUP Dr. Mohammad Hoesin Palembang. Kemudian pengaruh motivasi kerja dan disiplin kerja terhadap motivasi ini ini diperkuat dari hasil uji determinasi bahwa antara motivasi kerja dan disiplin kerja saling berkaitan dalam berkonstribusi sebesar $69 \%$ mempengaruhi kinerja karyawan instalasi gizi RSUP Dr. Mohammad Hoesin Palembang. Apabila dilihat dari hasil analisis regresi berganda dan uji parsial pengaruh diantara kedua variabel yang diteliti terhadap kinerja karyawan dikatakan bahwa motivasi kerja berpengaruh lebih besar apabila dibandingkan dengan variabel disiplin kerja.

Penjelasan dari hasil-hasil tersebut sejalan dengan teori yang dinyatakan oleh (Kasmir, 2016), bahwa motivasi kerja dan disiplin kerja adalah beberapa faktor yang mempengaruhi kinerja karyawan. Dan dari teori ini memperkuat hasil dari penelitian ini, bahwa faktor motivasi kerja dan disiplin kerja akan mempengaruhi kinerja karyawan. Selain sejalan dengan teori, hasil penelitian ini menunjukkan adanya relevansi dengan hasil penelitian yang telah dilakukan oleh peneliti terdahulu seperti penelitan dari penelitian (Farhah, Ahiri, and Ilham 2020), (Marpaung 2014), (Setiawan, 2013), dan (Suwanto 2019). Ke empat peneliti ini telah melakukan penelitian dengan variabel yang sama yaitu motivasi kerja dan disiplin kerja terhadap kinerja karyawan, hasil penelitian mereka juga mengatakan hal yang sama bahwa ada pengaruh atas variabel yang diteliti yaitu motivasi kerja dan disiplin kerja terhadap kinerja karyawan.

Pengaruh motivasi kerja terhadap kinerja karyawan, memberikan gambaran bahwa dengan adanya motivasi kerja akan dapat memberi konstribusi dalam meningkatkan kinerja karyawan. Melalui motivasi kerja bagi karyawan terlebih pada kondisi pandemi covid-19 yang terjadi saat ini. Motivasi yang dilakukan berupa menciptakan kondisi perkerjaan yang nyaman dan menciptakan rasa tenang, memberikan fasilitas kerja yang memadai, dan memberikan pengakuan atas pekerjaan yang dilakukan karyawan bahwa karyawan telah melakukan pekerjaan dengan baik.

Pengaruh disiplin kerja terhadap kinerja karyawan, memberikan gambaran bahwa disiplin kerja memiliki konstribusi dalam meningkatkan kinerja karyawan. Melalui disiplin kerja maka dapat membentuk sikap taat dan keteraturan karyawan terhadap nilai dan aturan yang ditetapkan perusahaan. Manajemen dapat mmbuat strategi berupa ketegasan sikap berkaitan dengan ketepatan waktu jam kerja, sikap mangkir bekerja yang dilakukan karyawan dan memastikan bahwa karyawan dapat mematuhi semua peraturan yang ada dilingkungan RSUP Dr. Mohammad Hoesin Palembang

\section{Kesimpulan}

Dari hasil penelitian yang dilakukan pada instalasi gizi RSUP Dr. Mohammad Hoesin Palembang beberapa simpulan yang dibuat mengenai kinerja karyawan, yaitu:

1. Ada pengaruh signifikan motivasi kerja dan disiplin kerja terhadap instalasi gizi RSUP Dr. Mohammad Hoesin Palembang. 
2. Ada pengaruh signifikan motivasi kerja terhadap instalasi gizi RSUP Dr. Mohammad Hoesin Palembang.

3. Ada pengaruh signifikan disiplin kerja terhadap instalasi gizi RSUP Dr. Mohammad Hoesin Palembang.

Dari hasil penelitian yang dapat dijadikan sebagai masukan bagi instalasi gizi RSUP Dr. Mohammad Hoesin Palembang, adalah:

1. Instalasi gizi RSUP Dr. Mohammad Hoesin Palembang harus dapat memberikan motivasi tinggi kepada karyawan agar para karyawan terdorong dan bersemangat dalam melaksanakan pekerjaan dan tanggung jawabnya. Adapun yang dijadikan masukan dalam pemberian motivasi ini terlebih dalam kondisi pandemic covid 19 ini adalah harus dapat menciptakan rasa nyaman sesuai kondisi kerja karyawan, memberikan fasilitas yang lengkap agar dapat meminimalisasi kekhawatiran karyawan atas pekerjaan yang dilakukannya, serta harus dapat mengapresiasi setiap kerja karyawan dengan baik sebagai bentuk pengakuan atas pekerjaan yang dilakukan karyawan tersebut.

2. Instalasi gizi RSUP Dr. Mohammad Hoesin Palembang penting untuk mengambil tindakan tegas kepada karyawan guna memperbaiki tingkat disiplin kerja karyawan. Pendisiplinan ini terutama berkaitan dengan tiga hal yaitu jam kerja, tingkat kehadiran dan kepatuhan atas aturan yang berlaku di RSUP Dr. Mohammad Hoesin Palembang.

\section{Referensi}

Afandi, P. (2016). Concept \& indicator: Human resource management concept \& indicator : Human Resource Management.

Mangkunegara, A.P. (2017). Manajemen sumber daya manusia perusahaan. Bandung: PT. Remaja Rosdakarya

Kasmir. (2016). Manajemen Sumber Daya Manusia (Teori Dan Praktik). In Manajemen Sumber Daya Manusia (Teori Dan Praktik),.

Edy, S. (2009). Manajemen sumber daya manusia. Jakarta: Kencana.

Farhah, A., Ahiri, J., \& Ilham, M. (2020). Pengaruh motivasi kerja dan disiplin kerja terhadap kinerja karyawan. Jurnal Online Program Studi Pendidikan Ekonomi.

Handoko, H. (2003). Manajemen Sumber Daya Manusia Edisi 2. Yogyakarta: BPFE

Hasibuan, S.P.M. (2014). Manajemen Sumber Daya Manusia. Jakarta: Bumi Aksara.

Marpaung, I. (2014). Pengaruh motivasi dan disiplin kerja terhadap kinerja karyawan (Studi Pada Karyawan Rumah Sakit Reksa Waluya Mojokerto). Jurnal Administrasi Bisnis S1 Universitas Brawijaya.

Veithzal, R. (2013). Manajemen sumber daya manusia untuk perusahaan dari teori ke praktik Manajemen Sumber Daya Manusia.

Setiawan, A. (2013). Pengaruh disiplin kerja dan motivasi terhadap kinerja karyawan pada Rumah Sakit Umum Daerah Kanjuruhan Malang. Jurnal Ilmu Manajemen (JIM).

Sugiyono. (2017). Metode penelitian kuantitatif, kualitatif dan R\&D. Bandung: PT Alfabeta.

Suwanto, S. (2019). Pengaruh disiplin kerja dan motivasi kerja terhadap kinerja karyawan pada Rumah Sakit Umum Tangerang Selatan. JENIUS (Jurnal Ilmiah Manajemen Sumber Daya 
Manusia).

\section{Copyrights}

Copyright for this article is retained by the author(s), with first publication rights granted to the journal.

This is an open-access article distributed under the terms and conditions of the Creative Commons Attribution license (http://creativecommons.org/licenses/by/4.0/) 